\title{
Reduction of glucose and insulin concentrations during in vitro incubation of human whole blood at different temperatures
}

\author{
Sigrid Beitland ${ }^{1,2 *}$, Helge Opdahl ${ }^{3}$, Trude Aspelin 4 , Peter A Torjesen ${ }^{5}$ and Torstein Lyberg ${ }^{4}$ \\ *Correspondence: sigrid.beitland@medisin.uio.no \\ 'Department of Anaesthesiology, Division of Emergencies and Critical Care, Oslo University Hospital, Postboks 4956 Nydalen, \\ N-0424 Oslo, Norway. \\ ${ }^{2}$ Institute of Clinical Medicine, Faculty of Medicine, University of Oslo, Postboks 1072, Blindern, N-0316 Oslo, Norway. \\ ${ }^{3}$ The Norwegian Center for NBC Medicine, Department of Acute Medicine, Division of Medicine, Oslo University Hospital, Postboks \\ 4956 Nydalen, N-0424 Oslo, Norway. \\ ${ }^{4}$ Department of Medical Biochemistry, Division of Diagnostics and Intervention, Oslo University Hospital, Postboks 4956 Nydalen, \\ $\mathrm{N}-0424$ Oslo, Norway. \\ ${ }^{5}$ Hormone Laboratory, Department of Endocrinology, Division of Medicine, Oslo University Hospital, Postboks 4959 Nydalen, N-0424 \\ Oslo, Norway.
}

\begin{abstract}
Background: Incubation of human whole blood at body temperature has been used in numerous studies without addition of glucose and insulin. The purpose of the study was to examine glucose concentration changes during in vitro incubation of human whole blood at different temperatures, and whether it was affected by addition of insulin and bacterial endotoxin. We also wanted to quantify changes in endogenous insulin concentrations during incubation for six hours at $37^{\circ} \mathrm{C}$.

Methods: Young, healthy and fasting males donated whole blood. Glucose concentrations were compared at baseline and after six hours incubation at $37^{\circ} \mathrm{C}, 22^{\circ} \mathrm{C}$ or $0^{\circ} \mathrm{C}$, in aliquots with and without addition of insulin and bacterial endotoxin. Glucose data are presented as mean ( \pm 1 standard deviation). Endogenous insulin concentrations in aliquots without addition were measured at baseline and after six hours incubation at $37^{\circ} \mathrm{C}$, data are shown as median (interquartile range). Results: Glucose concentration at baseline was $5.3( \pm 0.6) \mathrm{mmol} / \mathrm{L}$. After incubation for six hours at different temperatures, the glucose level at $37{ }^{\circ} \mathrm{C}$ was $1.0( \pm 0.5) \mathrm{mmol} / \mathrm{L}(\mathrm{p}<0.01)$, at $22^{\circ} \mathrm{C} 3.0( \pm 0.6) \mathrm{mmol} / \mathrm{L}(\mathrm{p}<0.01)$, and at $0{ }^{\circ} \mathrm{C} 5.4( \pm 0.7)$ $\mathrm{mmol} / \mathrm{L}(\mathrm{p}=0.95)$. The decline in glucose concentration seemed to be independent of addition of insulin and bacterial endotoxin. Endogenous insulin levels decreased from baseline 48 (36-94) pmol/L to 23 (18-27) pmol/L (p=0.03) during six hours incubation at $37^{\circ} \mathrm{C}$.

Conclusions: Glucose concentration was markedly reduced during in vitro incubation of whole blood from healthy volunteers for six hours at $37^{\circ} \mathrm{C}$ and $22^{\circ} \mathrm{C}$, but was maintained at $0{ }^{\circ} \mathrm{C}$. Endogenous insulin level after six hours incubation of whole blood at $37^{\circ} \mathrm{C}$ was more than halved compared to baseline. During in vitro studies of glucose and/or insulin effects lasting for hours, measures must be undertaken to maintain stable glucose and/or insulin concentrations.
\end{abstract}

Keywords: Glucose, carbohydrate, insulin, hormone, human, in vitro, homeostasis

\section{Background}

Changes in blood glucose levels in vivo may reflect underlying disturbances in the metabolic homeostasis. Hyperglycaemia and/or insulin resistance has been shown to adversely affect clinical outcomes in both diabetic and non-diabetic patients [1]. This has been confirmed for several patient categories, including pregnant women [2], patients with diabetes mellitus [3], acute myocardial infarction [4] and acute stroke [5]. Elevated glucose concentration has been associated with unfavourable outcome in both patients undergoing coronary artery bypass grafting [6] and in intensive care unit (ICU) patients [7]. Stressinduced hyperglycaemia is also a clinical relevant problem; as it has been shown to occur in a significant number of patients intraoperatively, postoperatively and during ICU stay [8].

The effects of hyperglycaemia and/or insulin resistance have been extensively studied during the last decades, utilizing both in vivo $[\mathbf{9 , 1 0 ]}$ and in vitro $[11,12]$ models. The two mentioned methodologies are principally different as several organs (liver [13], pancreas [14], muscles [15], endothelium [16] and adipose tissue [17]) as well as regulatory mechanisms (hypothalamicpituitary-adrenal axis [18]) influences the concentration of glucose and/or insulin in the human body, but not in isolated blood samples. Glucose and/or insulin concentration changes in aliquots during incubation might therefore be different from glucose and/or insulin homeostasis in vivo.

There are publications showing decreased glucose concentration during storage of blood due to glucolysis that can be inhibited by addition of antiglycolytic agents $[19,20,21]$. The decreases in glucose concentration seem to be dependent on both time and temperature, and result in 
Beitland et al. Journal of Diabetes Research and Clinical Metabolism 2013,

http://www.hoajonline.com/journals/pdf/2050-0866-2-11.pdf

doi: $10.7243 / 2050-0866-2-11$

Table 1. Study design: Aliquots of whole blood with different additions and measurements.

\begin{tabular}{lcccccc}
\hline $\begin{array}{l}\text { Aliquot } \\
\text { incubation } \\
\text { procedure }\end{array}$ & $\begin{array}{c}\text { Number } \\
(\mathbf{n}=)\end{array}$ & $\begin{array}{c}\text { Insulin } \\
\text { added } \\
(\mathbf{n m o l} / \mathrm{L})\end{array}$ & $\begin{array}{c}\text { E. Coli LPS } \\
\text { added } \\
(\boldsymbol{\mu g} / \mathbf{m L})\end{array}$ & $\begin{array}{c}\text { Glucose } \\
\text { measured }\end{array}$ & $\begin{array}{c}\text { Insulin } \\
\text { measured }\end{array}$ & $\begin{array}{c}\text { Lactate } \\
\text { measured }\end{array}$ \\
\hline $\begin{array}{l}37^{\circ} \mathrm{C} \\
\text { without } \\
\text { additions }\end{array}$ & 6 & No & No & No & $\begin{array}{c}0 \text { and } 6 \\
\text { hours }\end{array}$ & No \\
$\begin{array}{l}37^{\circ} \mathrm{C} \\
\text { with } \\
\text { additions }\end{array}$ & 6 & 30 & 1 & Every hour & No & No \\
$\begin{array}{l}37^{\circ} \mathrm{C} \\
\text { without } \\
\text { additions }\end{array}$ & 8 & No & No & Every hour & No & 6 hours \\
$\begin{array}{l}22^{\circ} \mathrm{C} \\
\text { without } \\
\text { additions }\end{array}$ & 8 & No & No & Every hour & No & 6 hours \\
$\begin{array}{l}0^{\circ} \mathrm{C} \\
\text { without } \\
\text { additions }\end{array}$ & 8 & No & No & Every hour & No & 6 hours \\
\hline
\end{tabular}

an increased lactate concentration [22]. In contrast, insulin concentration was in a previous study stable for six hours in room temperature, and 72 hours at $4^{\circ} \mathrm{C}[23]$. The stability of endogenous glucose and insulin concentrations in human whole blood at different temperatures is not sufficiently quantified in previous studies; neither is the possible effect of insulin and endotoxin addition. The purpose of the study was to examine glucose concentration changes during in vitro incubation of human whole blood at body temperature, room temperature and placed on ice, and whether it was affected by addition of insulin and bacterial endotoxin. We also wanted to quantify changes in endogenous insulin concentrations during incubation for six hours at $37^{\circ} \mathrm{C}$.

\section{Methods}

\section{Study population}

Healthy males aged from 27 to 44 years donated blood after an overnight fast. The Regional Committee for Medical Research Ethics approved the study, and all donors gave oral and written informed consent before participation.

\section{Study design}

Heparinised whole blood from each donor was divided in aliquots of $2 \mathrm{~mL}$, whereof some were added insulin and $E$. Coli LPS. Aliquots were then incubated for 6 hours in an incubator $\left(37^{\circ} \mathrm{C}\right)$, at room temperature $\left(22^{\circ} \mathrm{C}\right)$ or placed on ice $\left(0^{\circ} \mathrm{C}\right)$. In selected aliquots glucose concentrations was measured every hour, insulin levels at baseline and 6 hours, and lactate levels after 6 hours (Table 1).

\section{Sampling and laboratory procedures}

Venous blood from each donor was collected in tubes containing lithium-heparin $17 \mathrm{IU} / \mathrm{mL}$ blood (Vacutainer, Becton Dickinson, Plymouth, UK) and immediately placed on ice. The blood from each donor was pooled and subsequently aliquoted into polystyrene tubes with ventilation cap (Falcon, Becton Dickinson Labware, NJ, USA), each containing $2 \mathrm{~mL}$ blood. To selected aliquots insulin (final concentration 30 $\mathrm{nmol} / \mathrm{L}$, Actrapid, Novo Nordisk, Bagsvaerd, Denmark) and bacterial endotoxin (final concentration $1 \mu \mathrm{g} / \mathrm{mL}$, E.coli LPS, serotype 026:B6, Difco Laboratories, Detroit, MI, USA) were added. The aliquots were incubated for 6 hours either in an incubator at $37^{\circ} \mathrm{C}$ (in an atmosphere of humidified $5 \% \mathrm{CO}_{2}$ and $95 \%$ air) at room temperature (measured in blood as 22 ${ }^{\circ} \mathrm{C}$ ) or placed on ice (measured in blood as $0^{\circ} \mathrm{C}$ ). Every hour the target temperature was confirmed in selected aliquots, and all tubes were agitated to obtain a homogenous solution.

Measurements of glucose, lactate and insulin concentrations Glucose concentrations ( $\mathrm{mmol} / \mathrm{L}$ ) were measured every hour during incubation at $37^{\circ} \mathrm{C}, 22^{\circ} \mathrm{C}$ and $0^{\circ} \mathrm{C}$, at body temperature both in aliquots with and without addition of insulin and E.Coli LPS (Table 1). Glucose levels were measured utilizing Accu-Chek Sensor meter with Accu-Chek Inform test strips (Hofmann- La Roche Ltd, Basel, Switzerland).

Lactate concentrations ( $\mathrm{mmol} / \mathrm{L}$ ) were measured in aliquots without additions after 6 hours incubation at $37^{\circ} \mathrm{C}, 22^{\circ} \mathrm{C}$ and $0^{\circ} \mathrm{C}$, respectively (Table 1). Lactate levels were measured using Arkray Lactate Pro test meter with Lactate Pro test strips (Arkray Factory Inc, Shiga, Japan). The same person did all glucose and lactate measurements on each experimental day.

Endogenous insulin concentrations ( $\mathrm{pmol} / \mathrm{L}$ ) were measured in aliquots without additions at baseline and after 6-hour incubation at $37{ }^{\circ} \mathrm{C}$ (Table 1). Insulin measurements were performed in plasma after centrifugation at $2000 \mathrm{~g}$ for 12 minutes at $4{ }^{\circ} \mathrm{C}$ and storage at $-70^{\circ} \mathrm{C}$. Insulin was measured by a radioimmunoassay kit (Linco Research Inc, St. Charles, MO, USA), intra-assay coefficient of variation was $<5 \%$. 


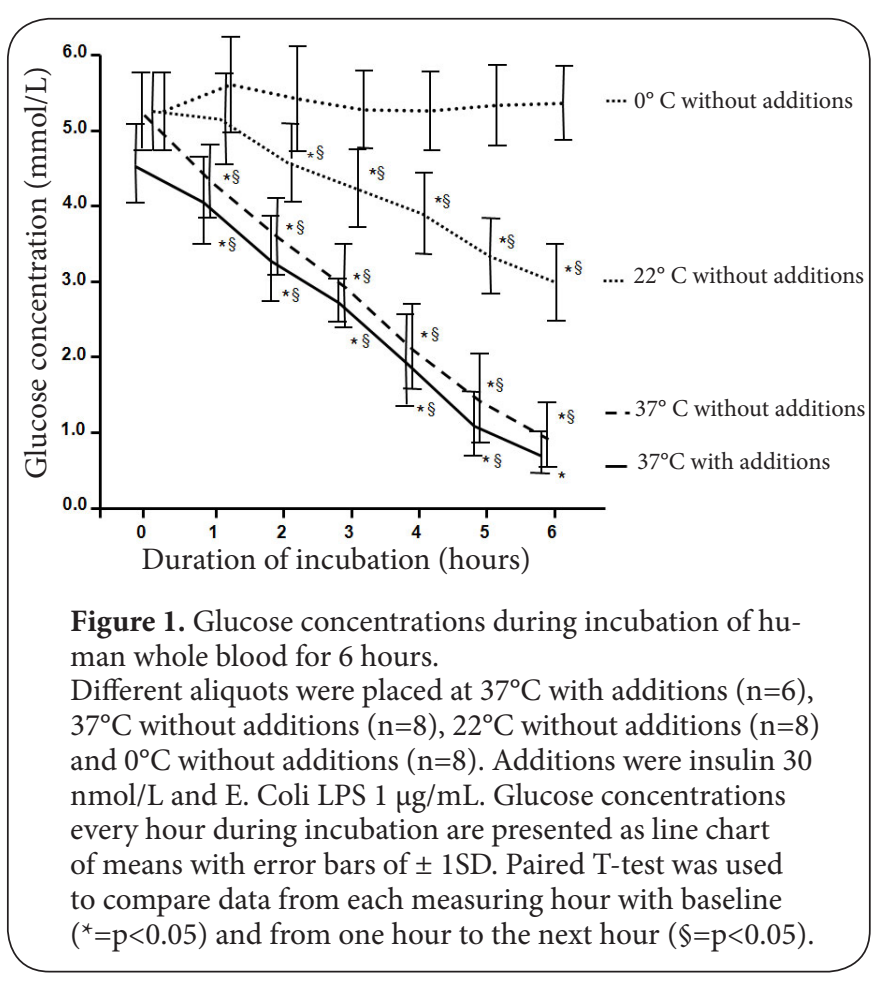

Table 2. Lactate concentrations ( $\mathrm{mmol} / \mathrm{L}$ ) after incubation of human whole blood for 6 hours. Paired T-test was used to compare aliquots incubated at $37^{\circ} \mathrm{C}$ versus $22^{\circ} \mathrm{C}\left({ }^{*}=\mathrm{p}<0.05\right)$ and aliquots incubated at $22^{\circ} \mathrm{C}$ versus $0{ }^{\circ} \mathrm{C}(\$=\mathrm{p}<0.05)$.

\begin{tabular}{cccc}
\hline Person number & $\mathbf{3 7}{ }^{\circ} \mathbf{C}$ & $\mathbf{2 2}^{\circ} \mathbf{C}$ & $\mathbf{0}^{\circ} \mathbf{C}$ \\
\hline 1 & 7.1 & 3.8 & 1.0 \\
2 & 8.8 & 4.4 & 1.1 \\
3 & 8.2 & 4.2 & 1.0 \\
4 & 7.6 & 3.7 & 0.8 \\
5 & 8.0 & 3.8 & 1.4 \\
6 & 7.8 & 3.6 & 0.9 \\
7 & 8.0 & 4.3 & 1.3 \\
8 & 9.9 & 4.4 & 1.2 \\
Mean $( \pm \mathrm{SD})$ & $8.2( \pm 0.8) *$ & $4.0( \pm 0.3) * \S$ & $1.1( \pm 0.2) \S$
\end{tabular}

\section{Statistical analysis}

Glucose and lactate data showed a normal distribution and are presented as mean ( \pm 1 standard deviation (SD)). Oneway ANOVA was used to analyze significant effects of time and/or temperature on glucose concentrations. Paired T-test was used to test the significance of a decline in glucose levels during incubation. Independent sample T-test was utilized to compare glucose concentrations at different temperatures and with different additions. Insulin data showed a skewed distribution and are presented as median (interquartile range (IQR)). Wilcoxon signed rank test was utilized to compare insulin concentrations at baseline and 6 hours. Statistical analyses was performed utilizing Statistical Package for Social Sciences
(SPSS), version 15.0 (SPSS Inc.,Chicago, IL, USA). Significance was accepted at $\mathrm{p}<0.05$.

\section{Results \\ Glucose concentrations}

At $37^{\circ} \mathrm{C}$ the blood glucose concentration in aliquots without additions declined from $5.3( \pm 0.6)$ to $1.0( \pm 0.5) \mathrm{mmol} / \mathrm{L}$ after 6 hours $(p<0.01)$; the mean decline was $0.7( \pm 0.2) \mathrm{mmol} / \mathrm{L} /$ hour, which was significant for each time interval. The decline in aliquots with additions was $0.6( \pm 0.3) \mathrm{mmol} / \mathrm{L} /$ hour, which was significant for each time interval except for from 5 to 6 hours. Independent samples T-test revealed that the decline in glucose concentrations was not significantly affected by additions of LPS and insulin (Figure 1).

At $22^{\circ} \mathrm{C}$ the blood glucose concentration declined from $5.3( \pm 0.6)$ to $3.0( \pm 0.6) \mathrm{mmol} / \mathrm{L}$ after 6 hours $(p<0.01)$; mean decline was $0.4( \pm 0.2) \mathrm{mmol} / \mathrm{L} /$ hour, which was significant for all time intervals except between 0 and 1 hour (Figure 1 ).

At $0{ }^{\circ} \mathrm{C}$ there was no detectable decline in glucose concentration during the incubation period as glucose level was $5.4( \pm 0.7) \mathrm{mmol} / \mathrm{L}$ after 6 hours $(\mathrm{p}=0.95)$ (Figure 1$)$.

\section{Lactate concentrations}

At $37^{\circ} \mathrm{C}$, lactate concentration was $8.2( \pm 0.8) \mathrm{mmol} / \mathrm{L}$ after 6 hours incubation, at $22^{\circ} \mathrm{C} 4.0( \pm 0.3) \mathrm{mmol} / \mathrm{L}$ and at $0{ }^{\circ} \mathrm{C} 1.1$ $( \pm 0.2) \mathrm{mmol} / \mathrm{L}$. Paired T-test revealed a significant difference in lactate level between $37^{\circ} \mathrm{C}$ and $22^{\circ} \mathrm{C}(\mathrm{p}<0.01)$, and between $22^{\circ} \mathrm{C}$ and $0{ }^{\circ} \mathrm{C}(\mathrm{p}<0.01)$ (Table 2).

\section{Insulin concentrations}

Wilcoxon signed rank test revealed that endogenous insulin concentration after incubation at $37^{\circ} \mathrm{C}$ for 6 hours was significantly reduced from baseline 48 (36-94) to 23 (18-27) $\mathrm{pmol} / \mathrm{L}(\mathrm{p}=0.03)$ (Figure 2).

\section{Discussion}

The main finding in this study was that glucose concentration was reduced to almost zero during 6 hours in vitro incubation of whole blood at body temperature. The decline in glucose concentration was independent of addition of insulin and bacterial endotoxin. At $22^{\circ} \mathrm{C}$ glucose level was reduced by approximately $50 \%$ of that at $37^{\circ} \mathrm{C}$ after 6 hours, while at $0^{\circ} \mathrm{C}$ glucose concentration was maintained. There was also $52 \%$ lowered endogenous insulin concentration at 6 hours and $37^{\circ} \mathrm{C}$ compared to baseline.

Glucolysis is known to cause falling glucose concentrations in blood samples after collection, and antiglycolytic agents can be added in order to maintain glucose levels $[19,20,21]$. Such antiglycolytic agents can interfere with cellular functions, and are therefore not used during studies of activated blood cells. Measurements of glucose concentrations during incubation of blood with different glucose additions have usually not been performed in previous studies [11,12], only the measured and/or calculated glucose level at baseline 


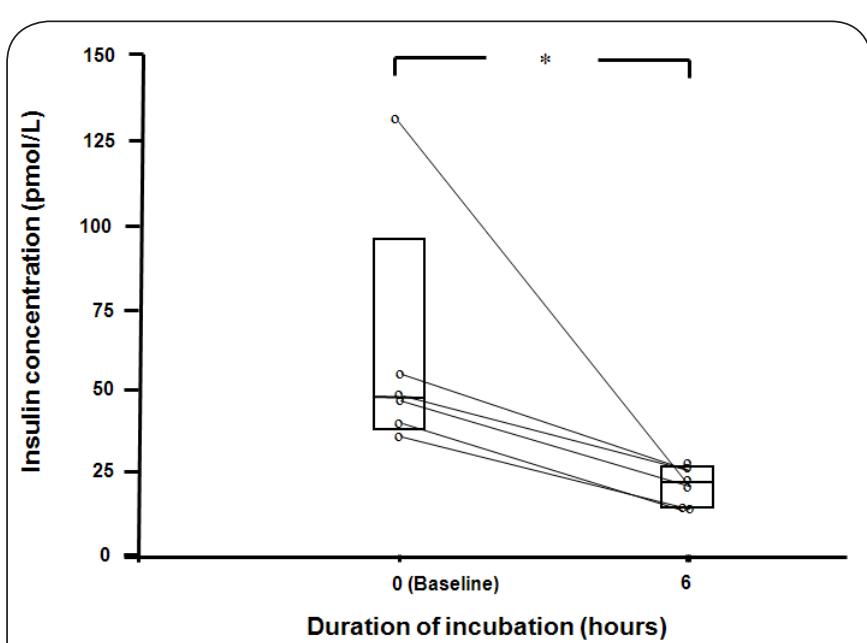

Figure 2. Insulin concentration during incubation of human whole blood at $37^{\circ} \mathrm{C}$ for 6 hours.

Insulin level before and after incubation are presented as box plots with medians in 25 th and 75 th percentile boxes in addition to individual values. Wilcoxon signed rank test was used to compare data from 6 hours with baseline $(n=6)$ $\left({ }^{*}=\mathrm{p}<0.05\right)$.

has been reported $[11,12]$. The present study revealed an almost linear, temperature-dependent decline in glucose concentration during incubation at body temperature, down to severely hypoglycaemic levels after 6 hours. As erythrocytes obtain their metabolic energy by glucolysis, and the same effect was observed in aliquots with and without insulin additions, we propose that the decline was independent of any effects of insulin [24]. This hypothesis is supported by the measured lactate concentration after 6 hours incubation, as lactate is the metabolic end product of glucolysis with 2 molecules of lactate generated for each molecule of glucose.

The addition of insulin has also been done in numerous in vitro experiments without measurements of insulin concentration during incubation. Insulin level at baseline is often reported and assumed to remain constant during incubation. In contrast, we found in the present study that the median endogenous insulin concentration was reduced by more than $50 \%$ during 6 hours incubation at $37^{\circ} \mathrm{C}$. This was unexpected, as insulin is mostly degraded in liver and kidney, but to some extent also in blood cells and extracellularly [25]. Insulin concentrations in normal whole blood has in previous studies been stable at room temperature for 5 hours [26] at $37^{\circ} \mathrm{C}$ insulin have been reported to be bound to human erythrocytes followed by subsequent internalization and degradation $[27,28]$. Thus, insulin is degraded by viable erythrocytes at $37^{\circ} \mathrm{C}$ while the erythrocytes are unable to degrade insulin at room temperature, presumably due to reduced metabolic activity at this temperature.

This study contributes new knowledge regarding glucose and insulin degradation in whole blood at different temperatures. Even if our samples were examined ex vivo, the same rate of degradation by blood cells can be expected to occur in vivo. Under normal circumstances, surrounding tissues replenish blood glucose and insulin continuously. When the glucose and glycogen reserves are exhausted, also the blood cells participate in creation of a hypoglycaemic state with degradation rates calculated from our results to be close to $20 \mathrm{~g}$ glucose/24 hours, which is in agreement with data from others $[29,30]$. Based on our results, we suggest that former publications regarding effects of glucose and/or insulin during in vitro incubation should be interpreted with caution, as the reported glucose and/or insulin concentrations may not be representative for the entire incubation period. To avoid hypoglycaemia we also suggest that glucose or other energy supply for cells should be added in future in vitro studies lasting for hours. Further, when glucose and/ or insulin effects are studied during incubation, measures should be undertaken to maintain stable glucose and/or insulin concentrations.

A limitation was the use of only one glucose measurement method as the accuracy of different glucose measurement techniques has lately been elucidated [31]. The present study does not deal with the mechanisms behind decline in glucose and insulin concentrations, the respective contributions of erythrocyte glucolysis and leukocyte metabolism has to be addressed in future studies. The main goal of this investigation was to examine glucose dynamics in relation to a commonly used method for examining various aspects of leukocyte function after activation ex vivo, i.e., by incubating whole blood at body temperature $\left(37^{\circ} \mathrm{C}\right)$ for several hours. As addition of insulin and bacterial endotoxin did not affect the glucose metabolism at $37^{\circ} \mathrm{C}$, it was unlikely to do so at lower temperatures. A comparison of insulin degradation at different temperatures could have been interesting, but the dynamics of insulin in blood per se was not focused upon in this investigation. Furthermore, the effect of exogenous glucose addition on glucose degradation during incubation should be addressed in future studies.

\section{Conclusions}

There is a considerable degradation of glucose in whole blood at body temperature. During in vitro incubation of whole blood from healthy volunteers, glucose concentration was markedly reduced, after 6 hours incubation down to almost zero. Reduction of glucose concentration seemed to be independent of addition of insulin and bacterial endotoxin. There was also significantly lowered endogenous insulin level after incubation of whole blood for 6 hours at $37^{\circ} \mathrm{C}$.

\section{Competing interests}

The authors declare that they have no competing interests.

\section{Authors' contributions}

$\mathrm{HO}$ and TL contributed to the conception and design of the study. $\mathrm{SB}$ recruited persons, performed the glucose and lactate analyses, and drafted the manuscript. TA was responsible for blood sample collection and handling, including the incubation procedure. PAT 
was responsible for the insulin concentration measurements. SB $\mathrm{HO}$ and TL analyzed and interpreted data, and all authors read and approved the final manuscript.

\section{Acknowledgement}

The authors would like to thank the volunteers who donated blood to the study.

\section{Publication history}

Received: 12-Dec-2012 Revised: 11-Jan-2013

Accepted: 21-Feb-2013 Published: 06-Mar-2013

\section{References}

1. Raju TA, Torjman MC and Goldberg ME: Perioperative blood glucose monitoring in the general surgical population. J Diabetes Sci Technol 2009, 3:1282-7. | Pdf | PubMed Abstract | PubMed Full Text

2. Scholl TO, Sowers $M$, Chen $X$ and Lenders $C$ : Maternal glucose concentration influences fetal growth, gestation, and pregnancy complications. Am J Epidemiol 2001, 154:514-20. | Article | PubMed

3. The effect of intensive treatment of diabetes on the development and progression of long-term complications in insulin-dependent diabetes mellitus. The Diabetes Control and Complications Trial Research Group. N Engl J Med 1993, 329:977-86. | Article | PubMed

4. Anselmino $M$, Wallander $M$, Norhammar $A$, Mellbin $L$ and Ryden $L$ : Implications of abnormal glucose metabolism in patients with coronary artery disease. Diab Vasc Dis Res 2008, 5:285-90. | Article | PubMed

5. Capes SE, Hunt D, Malmberg K, Pathak P and Gerstein HC: Stress hyperglycemia and prognosis of stroke in nondiabetic and diabetic patients: a systematic overview. Stroke 2001, 32:2426-32. | Article | PubMed

6. Furnary AP, Gao G, Grunkemeier GL, Wu Y, Zerr KJ, Bookin SO, Floten HS and Starr A: Continuous insulin infusion reduces mortality in patients with diabetes undergoing coronary artery bypass grafting. J Thorac Cardiovasc Surg 2003, 125:1007-21. | Article | PubMed

7. van den Berghe $G$, Wouters $P$, Weekers $F$, Verwaest $C$, Bruyninckx F, Schetz M, Vlasselaers D, Ferdinande P, Lauwers P and Bouillon R: Intensive insulin therapy in critically ill patients. N Engl J Med 2001, 345:1359-67. | Article | PubMed

8. Keegan MT, Goldberg ME, Torjman MC and Coursin DB: Perioperative and critical illness dysglycemia--controlling the iceberg. J Diabetes Sci Technol 2009, 3:1288-91. | Pdf | PubMed Abstract | PubMed Full Text

9. Krogh-Madsen R, Moller K, Dela F, Kronborg G, Jauffred S and Pedersen BK: Effect of hyperglycemia and hyperinsulinemia on the response of IL-6, TNF-alpha, and FFAs to low-dose endotoxemia in humans. Am J Physiol Endocrinol Metab 2004, 286:E766-72. | Article | PubMed

10. Soop M, Duxbury H, Agwunobi AO, Gibson JM, Hopkins SJ, Childs C, Cooper RG, Maycock P, Little RA and Carlson GL: Euglycemic hyperinsulinemia augments the cytokine and endocrine responses to endotoxin in humans. Am J Physiol Endocrinol Metab 2002, 282:E127685. | Article | PubMed

11. Hancu N, Netea MG and Baciu I: High glucose concentrations increase the tumor necrosis factor-alpha production capacity by human peripheral blood mononuclear cells. Rom J Physiol 1998, 35:325-30. | PubMed

12. Morohoshi M, Fujisawa K, Uchimura I and Numano F: Glucosedependent interleukin 6 and tumor necrosis factor production by human peripheral blood monocytes in vitro. Diabetes 1996, 45:954-9. Article | PubMed

13. Vanhorebeek I, De Vos R, Mesotten D, Wouters PJ, De Wolf-Peeters $C$ and Van den Berghe G: Protection of hepatocyte mitochondrial ultrastructure and function by strict blood glucose control with insulin in critically ill patients. Lancet 2005, 365:53-9. | Article | PubMed

14. Mandrup-Poulsen T, Bendtzen K, Nerup J, Dinarello CA, Svenson M and Nielsen JH: Affinity-purified human interleukin I is cytotoxic to isolated islets of Langerhans. Diabetologia 1986, 29:63-7. | Article | PubMed

15. Khanna S, Roy S, Packer L and Sen CK: Cytokine-induced glucose uptake in skeletal muscle: redox regulation and the role of alpha-lipoic acid.
Am J Physiol 1999, 276:R1327-33. | Article | PubMed

16. Langouche L, Vanhorebeek I, Vlasselaers D, Vander Perre S, Wouters PJ, Skogstrand K, Hansen TK and Van den Berghe G: Intensive insulin therapy protects the endothelium of critically ill patients. J Clin Invest 2005, 115:2277-86 | Article | PubMed Abstract | PubMed Full Text

17. Krogh-Madsen R, Plomgaard P, Keller P, Keller $C$ and Pedersen BK: Insulin stimulates interleukin-6 and tumor necrosis factor-alpha gene expression in human subcutaneous adipose tissue. Am J Physiol Endocrinol Metab 2004, 286:E234-8. | Article | PubMed

18. Van der Poll T and Lowry SF: Epinephrine inhibits endotoxin-induced IL-1 beta production: roles of tumor necrosis factor-alpha and IL-10. Am J Physiol 1997, 273:R1885-90. | Article | PubMed

19. le Roux CW, Wilkinson SD, Pavitt DV, Muller BR and Alaghband-Zadeh J: A new antiglycolytic agent. Ann Clin Biochem 2004, 41:43-6. | Article | PubMed

20. Mikesh LM and Bruns DE: Stabilization of glucose in blood specimens: mechanism of delay in fluoride inhibition of glycolysis. Clin Chem 2008, 54:930-2. | Article | PubMed

21. Chan AY, Swaminathan R and Cockram CS: Effectiveness of sodium fluoride as a preservative of glucose in blood. Clin Chem 1989, 35:3157. | Pdf | PubMed

22. Astles $R$, Williams $C P$ and Sedor $F$ : Stability of plasma lactate in vitro in the presence of antiglycolytic agents. Clin Chem 1994, 40:1327-30. I Pdf | PubMed

23. Oddoze C, Lombard E and Portugal H: Stability study of 81 analytes in human whole blood, in serum and in plasma. Clin Biochem 2012, 45:464-9. | Article | PubMed

24. Newsholme EA and Dimitriadis G: Integration of biochemical and physiologic effects of insulin on glucose metabolism. Exp Clin Endocrinol Diabetes 2001, 109 Suppl 2:S122-34. | Article | PubMed

25. Duckworth WC, Bennett RG and Hamel FG: Insulin degradation: progress and potential. Endocr Rev 1998, 19:608-24. | Article | PubMed

26. Walters $E$, Henley $R$ and Barnes I: Stability of insulin in normal whole blood. Clin Chem 1986, 32:224. | Article | PubMed

27. Gambhir KK, Nerurkar SG, Das PD, Archer JA and Henry WL, Jr.: Insulin binding and degradation by human erythrocytes at physiological temperature. Endocrinology 1981, 109:1787-9. | Article | PubMed

28. Nerurkar SG and Gambhir KK: Insulin internalization in human erythrocytes. Diabetologia 1984, 26:89. | Article | PubMed

29. Levine R and Haft DE: Carbohydrate homeostasis. I. N Engl J Med 1970, 283:175-83. | Article | PubMed

30. Levine R and Haft DE: Carbohydrate homeostasis. N Engl J Med 1970 283:237-46. | Article | PubMed

31. Pitkin $A D$ and Rice MJ: Challenges to glycemic measurement in the perioperative and critically ill patient: a review. J Diabetes Sci Technol 2009, 3:1270-81. | Article | PubMed Abstract | PubMed Full Text

\section{Citation:}

Beitland S, Opdahl H, Aspelin T, Torjesen P A and Lyberg $T$ : Reduction of glucose and insulin concentrations during in vitro incubation of human whole blood at different temperatures. Journal of Diabetes Research and Clinical Metabolism 2013, 2:11.

http://dx.doi.org/10.7243/2050-0866-2-11 